\title{
MODELING OF MUSHROOMS (AGARICUS BISPORUS) OSMOTIC DEHYDRATION PROCESS IN SUGAR BEET MOLASSES
}

\author{
$\breve{S ̆ u p u t ~ Z . ~ D a n i j e l a ~}^{1}$, Vladimir S. Filipović ${ }^{1}$, Biljana Lj. Lončar ${ }^{1}$, Milica R. Nićetin ${ }^{1}$, Violeta M. Knežević ${ }^{1}$, \\ Jasmina M. Lazarević ${ }^{2}$, Dragana V. Plavšić ${ }^{2}$ \\ ${ }^{1}$ University of Novi Sad, Faculty of Technology Novi Sad, 21000 Novi Sad, Bulevar cara Lazara 1, Serbia \\ ${ }^{2}$ University of Novi Sad, Institute of Food Technology, 21000 Novi Sad, Bulevar cara Lazara 1, Serbia
}

\begin{abstract}
Mushrooms (Agaricus bisphorus) were osmotically dehydrated in sugar beet molasses solutions at concentrations of $60 \%, 70 \%$ and $80 \%$ d.m., at operating temperatures of $25{ }^{\circ} \mathrm{C}, 35{ }^{\circ} \mathrm{C}$ and $45{ }^{\circ} \mathrm{C}$ during $0.5 \mathrm{~h}, 1 \mathrm{~h}, 1.5 \mathrm{~h}, 2 \mathrm{~h}, 3 \mathrm{~h}$, and 5 hours. Moisture content, water activity $\left(\mathrm{a}_{\mathrm{w}}\right)$, microbiological parameters (total plate counts, Enterobacteriaceae, total yeasts and moulds count) and content of mineral elements (potassium, magnesium, iron and calcium) were determined in the osmodehydrated mushroom samples. Response surface methodology and analysis of variance were selected to estimate the main effects of the process variables (temperature, time, concentration) on process performance and selected mushroom attributes (microbiological counts, chemical composition and mineral content). Increase in the values of applied osmotic process parameters led to the significant increase in the content of minerals (for example, an increase in $\mathrm{K}$ and $\mathrm{Ca}$ content by $269.42 \%$ and $939.03 \%$, respectively) and a decrease in $\mathrm{a}_{\mathrm{w}}$ values (from 0.941 to 0.811 ), decrease in microbiological load and relative protein content (decrease by $33.07 \%$ ), indicating a possibility for prolonged shelf life and suitability for further processing. The osmodehydrated mushrooms could be considered as ingredients for new functional (semi)products due to improved nutritive profile.
\end{abstract}

Key words: mineral composition, water loss, solid gain, microbiological load, chemical composition

\section{INTRODUCTION}

Osmotic dehydration involves the immersion of a substrate (food) in a solution of high concentration, which partially dehydrates the food (Mújica-Paz, Valdez-Fragoso, Lopez-Malo, Palou \& Welti-Chanes, 2003; Erle \& Schubert, 2001). The driving force for water removal is the concentration gradient that is established on the opposite sides of the cell membrane.
This gradient causes two counter currents: dissolved substances of osmotic solution diffuse into the material being treated whilst water from the material flows into osmotic solution (Qiu, Zhang, Tang, Adhikari \& Cao, 2019; Ciurzyńska, Kowalska, Czajkowska \& Lenart, 2016; Ahmed, Qazi \& Jamal, 2016). Water is removed by capillary forces and diffusion, 
while counter current leaching and solute uptake are transmitted by diffusion (Shi \& Xue, 2009; Rahman \& Perera, 2007). Both flows depend on the cellular structure and membrane permeability (Fernandes, Gallão \& Rodrigues, 2009; Amami et al. 2007).

Products with reduced water content are obtained by osmotic dehydration. They are classified as partially preserved (minimally processed) products of high quality with prolonged shelf life (Silva, Fernandes \& Mauro, 2014). Intermediate moisture foods (IMF) are gaining in importance in widespread use because their characteristics are similar to fresh food products but shelf life is extended (Qiu, Zhang, Tang, Adhikari \& Cao, 2019). If a fresh appearance of a dehydrated product is required, the effect of dehydration must be at least $30 \%$, which makes such products moderately stable and could be further processed (dried, frozen or treated with additives) (Khan, 2012; Phisut, 2012) in the dairy, bakery or confectionery industries.

Choice regarding proper osmotic solution is important factor for successful dehydration, and this decision is mainly influenced by the water loss/solid gain ratio. In the case of osmotic solution with lower concentration - the components penetrate in deeper layers of the treated material (Rodrigues \& Mauro, 2004), while higher osmotic solution concentrations lead to faster water loss (Waliszewski, Delgado \& Garcia, 2002). The osmotic solution must have a low value of water activity $\left(\mathrm{a}_{\mathrm{w}}\right)$, an acceptable sensory quality and must achieve food safety requirements. Potential solutions are sucrose, glucose, $\mathrm{NaCl}$, corn syrup, starch concentrates, etc., which are selected according to the dehydrated product properties (Ahmed, Qazi \& Jamal, 2016). Alternative osmotic solutions, such as maple syrup, high fructose corn syrup, honey, ethanol, etc., have been attracting more attention due to high dehydration rates, optimal rehydration capacity, and negligible sensory effect on the substrate (Qiu, Zhang, Tang, Adhikari \& Cao, 2019).

During osmotic dehydration, simultaneously with the diffusion of water from the tissue into the surrounding solution there is an antidote diffusion of dissolved substances from the osmotic solution into the surface layers of the treated material (Rastogi \& Raghavarao, 2004; Chiralt \& Fito, 2003). Sugar beet molasses has been recognized as suitable osmotic solution due to its exceptional and complex chemical and nutritional composition. Molasses is an important by-product of sugar beet/sugar cane refining industry, remaining after no more sugar can be extracted by crystallization from the raw crop (Šarić et al., 2016). Cane and beet molasses are viscous polycomponent systems with a high dry matter content (around 80\%) and are significant source of many micronutrients (in the dissolved state), especially potassium, calcium, iron, magnesium and the vitamin B complex (Sauvant, Perez \& Tran, 2004). From a nutritional point of view, sugar beet molasses significantly enriches the content that is dehydrated in terms of minerals and vitamins (Cvetković et al., 2019; Lončar et al., 2015; Nićetin et al., 2015a; Nićetin et al., 2015b). Some investigations were conducted using sugar beet molasses as osmotic solution for dehydration of plant origin food (Knežević et al., 2019; Nićetin et al., 2017; Koprivica, Pezo, Ćurčić, Lević \& Šuput, 2014; Mišljenović, Koprivica, Jevrić \& Lević, 2011) and animal origin food (Šuput et al., 2019; Ćurčić, Pezo, Filipović, Nićetin \& Knežević, 2015; Filipović et al., 2014).

In previous works, mushrooms were osmotically pretreated/treated with different solutions: sucrose, citric acid, but mostly $\mathrm{NaCl}$ solution (González-Pérez et al., 2019; Darvishi, Azadbakht \& Noralahi, 2018; Gupta, Bhat, Chauhan, Ahmed \& Malik, 2015; Doymaz, 2014), at different process parameters (concentration, time, etc.). The aim of the study presented in this paper was to investigate and mathematically model the effects of varying processing parameters applied during the osmotic dehydration of mushrooms in sugar beet molasses on basic osmodehydration responses (water loss, solid gain, dry matter content), microbiological parameters, mineral and chemical composition of treated mushrooms.

\section{MATERIALS AND METHODS}

\section{Sample preparation}

Fresh mushrooms (Agaricus bisporus) were bought at a local greengrocery, after which their basic composition was determined, given in Supplementary material, Tables S1 and S2. Mushrooms were wiped with a damp cloth, cut into $5 \mathrm{~mm}$-slices, after which they were immersed in sugar beet molasses diluted to the concentrations of $60 \%, 70 \%$ and $80 \%$ of dry 
matter (d.m.). Basic composition of used sugar beet molasses is given in Table 1. The sample (mushroom slices) to osmotic solution (molasses) weight ratio was 1:5. The process was performed in laboratory jars at temperatures of 25,35 and $45^{\circ} \mathrm{C}$ under atmospheric pressure, in a constant temperature chamber (KMF 115 1, Binder, Germany). The samples were stirred every 15 minutes.

Processing conditions regarding stirring, intensity, duration and frequency were the same for all experimental runs, so the results could be comparable. Process duration was varied between process times of $0.5,1,1.5,2,3$, and 5 hours. After dehydration treatment, the samples were rapidly rinsed with running water, absorbed from excess water and further processed for the required tests.

Table 1.

Sugar beet molasses basic composition

\begin{tabular}{lc}
\hline Composition & $\begin{array}{c}\text { Content } \\
\left(\boldsymbol{\%}_{\text {d.m. }}\right)\end{array}$ \\
\hline Proteins & 24.43 \\
Carbohydrates & 26.22 \\
Ash & 9.17 \\
& $(\mathbf{m g} / \mathbf{k g})$ \\
$\mathrm{K}$ & 14640 \\
$\mathrm{Ca}$ & 2050 \\
$\mathrm{Mg}$ & 2420 \\
$\mathrm{Fe}$ & 47.2 \\
\hline
\end{tabular}

Moisture content was determined at $105{ }^{\circ} \mathrm{C}$ until constant weight was achieved (according to AOAC, 2000).

Water activity values $\left(a_{w}\right)$ were determined on a TESTO 650 water activity tester (Testo, Inc., 40 White Lake Rd, Sparta, NJ, USA) with a special probe with an accuracy of \pm 0.001 at $25^{\circ} \mathrm{C}$.

\section{Microbiological counts}

Determination of total plate counts (TPC) was performed according to ISO 4833:2013.

The determination of Enterobacteriaceae was determined according to ISO 21528-2:2017.

The determination of the total yeasts and moulds count (TYMC) was made according to the ISO 21527-2: 2008.

\section{Content of mineral elements}

Content of potassium $(\mathrm{K})$, magnesium $(\mathrm{Mg})$, iron $(\mathrm{Fe})$ and calcium $(\mathrm{Ca})$ was performed according to ISO 6869:2000.

\section{Calculations}

Osmotic dehydration process responses of dry matter content (DMC), water loss (WL) and solid gain (SG) were calculated and presented as mean values and standard deviation of three parallel runs:

$$
\begin{aligned}
& D M C=\frac{m_{d}}{m_{i}} \cdot 100 \% \\
& W L=\frac{m_{i} z_{i}-m_{f} z_{f}}{m_{i}}\left[\frac{g}{g_{\text {initialsample }(i . s .)}}\right] \\
& S G=\frac{m_{f} s_{f}-m_{i} s_{i}}{m_{i}}\left[\frac{g}{g_{i . s}}\right]
\end{aligned}
$$

where $m_{d}, m_{i}$ and $m_{f}$ are dry matter, initial and final samples mass $(\mathrm{g})$, respectively; $\mathrm{z}_{\mathrm{i}}$ and $\mathrm{z}_{\mathrm{f}}$ are the initial and final water fraction mass $\left(g_{\text {water }} / g_{\text {sample }}\right)$, respectively; $s_{i}$ and $s_{f}$ are the initial and final total solids fraction mass ( $g_{\text {total }}$ solids $/ \mathrm{g}_{\text {sample }}$, respectively.

\section{Response Surface Methodology}

Response Surface Methodology (RSM) and Analysis of Variance (ANOVA) were selected to estimate the main effects of the process variables on osmodehydration process, microbiological, and compositional responses during osmotic dehydration of mushroom samples.

The independent variables were process time $\left(\mathrm{X}_{1}\right)$, process temperature $\left(\mathrm{X}_{2}\right)$ and concentration of molasses as an osmotic solution $\left(\mathrm{X}_{3}\right)$. The dependent variables observed were osmotic dehydration responses: DMC $\left(\mathrm{Y}_{1}\right)$, WL $\left(\mathrm{Y}_{2}\right), \mathrm{SG}\left(\mathrm{Y}_{3}\right), \mathrm{a}_{\mathrm{w}}\left(\mathrm{Y}_{4}\right)$; microbiological responses: TPC $\left(\mathrm{Y}_{5}\right)$, TYMC $\left(\mathrm{Y}_{6}\right)$; mineral responses: $\mathrm{K}\left(\mathrm{Y}_{7}\right), \mathrm{Mg}\left(\mathrm{Y}_{8}\right), \mathrm{Ca}\left(\mathrm{Y}_{9}\right), \mathrm{Fe}\left(\mathrm{Y}_{10}\right)$ and chemical responses: Proteins $\left(\mathrm{Y}_{11}\right)$, Sugars $\left(\mathrm{Y}_{12}\right)$ and Ash $\left(\mathrm{Y}_{13}\right)$.

Models were fitted to the response surface generated by the experiment. The model used was function of the variables:

$Y_{k}=f_{k}($ time, temperature, concentration) $(4)$

The following second order polynomial (SOP) model was fitted to the data. Thirteen models of the following form were developed to relate thirteen responses $(\mathrm{Y})$ to three process variables $(\mathrm{X})$ : 


$$
\mathrm{Y}_{\mathrm{k}}=\beta_{\mathrm{k} 0}+\sum_{\mathrm{i}=1}^{3} \beta_{\mathrm{ki}} \mathrm{X}_{\mathrm{i}}+\sum_{\mathrm{i}=1}^{3} \beta_{\mathrm{kii}} \mathrm{X}_{\mathrm{i}}^{2}+\sum_{\mathrm{i}=1}^{2} \sum_{\mathrm{j}=\mathrm{i}+1}^{3} \beta_{\mathrm{kij}} \mathrm{X}_{\mathrm{i}} \mathrm{X}_{\mathrm{j}}, \mathrm{k}=1-13
$$

where $\beta_{\mathrm{kij}}$ are constant regression coefficients. ANOVA and RSM were performed using StatSoft Statistica, for Windows, ver. 12 program. The model was obtained for each dependent variable (or response) where factors were rejected when their significance level was less than $95 \%$.

\section{RESULTS AND DISCUSSION}

\section{Analysis of the osmotic dehydration process responses}

The untreated, raw mushrooms were characterized by DMC and $\mathrm{a}_{\mathrm{w}}$ values of $8.51 \pm 0.31 \%$ and $0.941 \pm 0.04$, respectively. Supplementary material, Table S1 displays the results obtained for the four osmotic dehydration process responses (DMC, WL, SG, $\mathrm{a}_{\mathrm{w}}$ ) that adequately represent the osmotic process. The maximal obtained values were: $58.33 \pm 1.11 \%$, $0.7953 \pm 0.0158 \mathrm{~g} / \mathrm{g}_{\text {i.s. }}, 0.1009 \pm 0.0016 \mathrm{~g} / \mathrm{g}_{\text {i.s. }}$ and $0.811 \pm 0.008$ for DMC, WL, SG and $\mathrm{a}_{\mathrm{w}}$, respectively. The osmodehydrated mushroom sample with the highest levels of DMC, WL and SG, and lowest level of $\mathrm{a}_{\mathrm{w}}$, indicating the most intensive mass transfer during the process, was obtained at the highest levels of applied technological parameters (process time of 5 hours, process temperature of $45{ }^{\circ} \mathrm{C}$ and molasses concentration of $80 \%$ ).

By analysing the statistically significant differrence between the values of different process time and constant process temperature and molasses concentration, it can be concluded that the effect of the process time had statistically significant influence on all four osmotic dehydration process parameters (for example, comparing significance level of runs no. from 49 to 54 , at $p<0.05$, see in Supplementary material, Table S1). This result harmonises with the findings from other similar studies which reported that the increase in immersion time led to higher moisture loss (Ispir \& Toğrul, 2009; Mundada, Hathan \& Maske, 2011). Figure 1 shows changes in DMC, WL, SG and $\mathrm{a}_{\mathrm{w}}$ during 5-h osmotic dehydration.

During osmodehydration, substrate is in contact with osmotic medium, which has high osmotic pressure and mass transfer is established with respect to time. As time is longer - osmodehydration effect is higher with respect to the evaluated process parameters (DMC, WL, SG). It was noted that the initial process period is the most important, since mass transfer phenomena are the fastest and have highest impact on further osmodehydration flow. Studies showed that exchange of masses occurred at a fastest rate within the initial $2 \mathrm{~h}$ followed by a reduction in drying rate during further processing time (Ramaswamy, 2005).

From the result presented in Supplementary material, Table S1 it can be seen that the temperature statistically significantly affected mass transfer in the process, manifested via statistically significant increase in DMC, WL and SG values and statistically significant decrease of $a_{w}$ values. Findings related to the osmodehydration of mushrooms in molasses are similar to those from other works which reported that temperature affects the rate of osmotic mass transfer (Tortoe, 2010) and that rise in process temperature accelerates water loss, while solid uptake is less affected (Khan, 2012; Tortoe, 2010). As in cases of the two previously analysed technology parameters, the effect of molasses concentration was also statistically significant on all four osmotic dehydration process responses, where the increase in the concentration of molasses solution significantly raised the values of the three responses (DMC, WL and SG), while $\mathrm{a}_{\mathrm{w}}$ significantly decreased. Other studies reported similar findings (Ispir \& Toğrul, 2009; Falade, Igbeka \& Ayanwuyi, 2007). The higher concentration of osmotic solution leads to greater osmotic pressure gradients, thereby leading to higher solid gain and water loss throughout the osmotic treatment period (Mundada, Hathan \& Maske, 2011).

\section{Effect on microbiological characteristics of the treated mushrooms}

The fresh mushroom samples were characterrized by $\log 10 \quad(\mathrm{CFU} / \mathrm{g})$ values of: $5.54 \pm 1.33 \times 10^{-2} ; 3.36 \pm 1.67 \times 10^{-2}$ and $4.64 \pm 1.11$ $\mathrm{x} 10^{-2}$ for TPC, TYMC and Enterobacteriaceae, respectively, (Supplementary material, Table S2). The highest reduction of present microorganisms and the lowest values of TPC and TYMC $(\log 10 \quad(\mathrm{CFU} / \mathrm{g})$ of $4.25 \pm 1.43 \times 10^{-2}$ and $2.99 \pm 8.82 \times 10^{-2}$, respecttively) are obtained at the highest levels of 


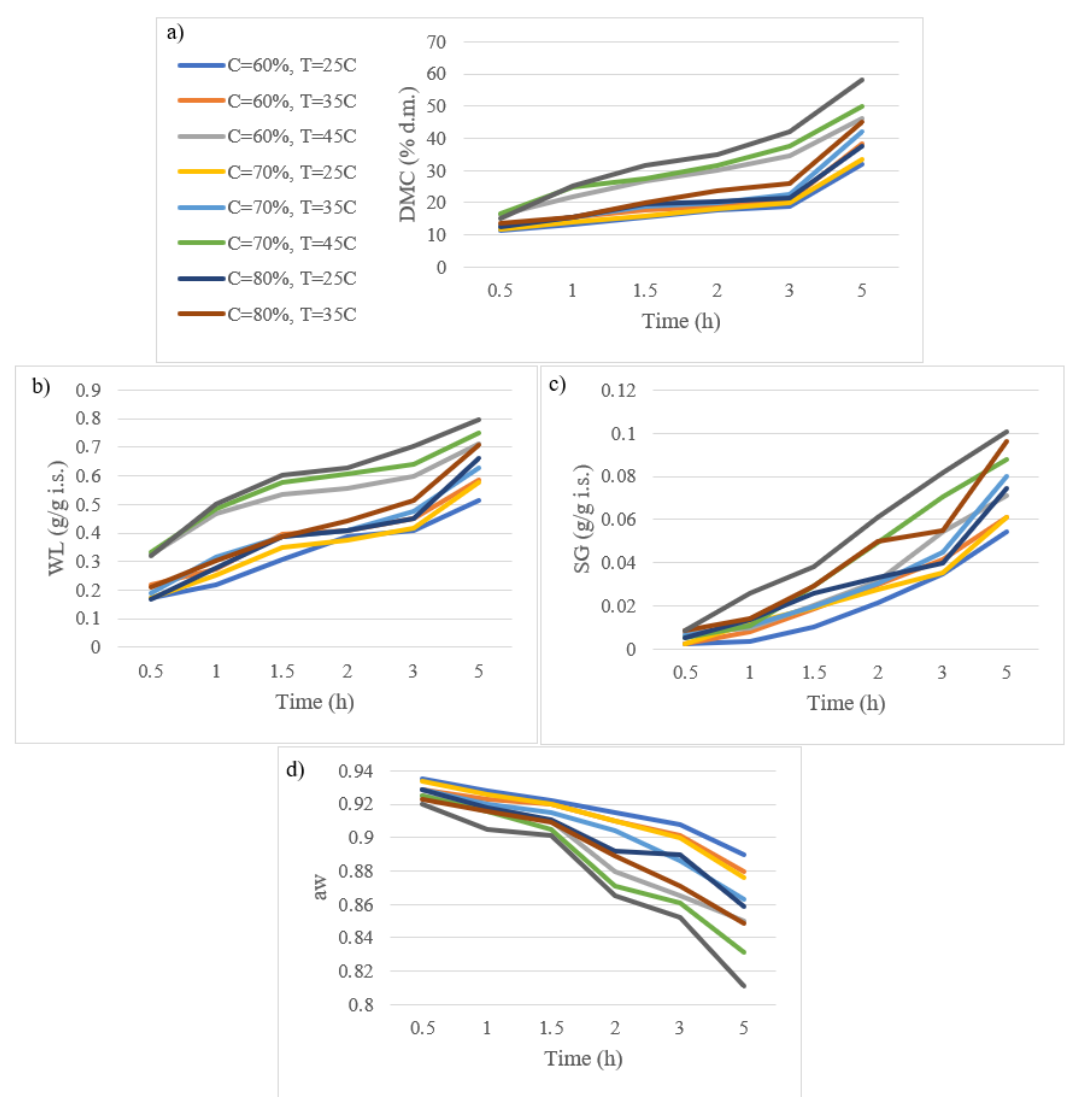

Figure 1. Dry matter content (DMC), water loss (WL), solid gain (SG) and $\mathrm{a}_{\mathrm{w}}$ changes in mushrooms during osmotic dehydration in sugar beet molasses
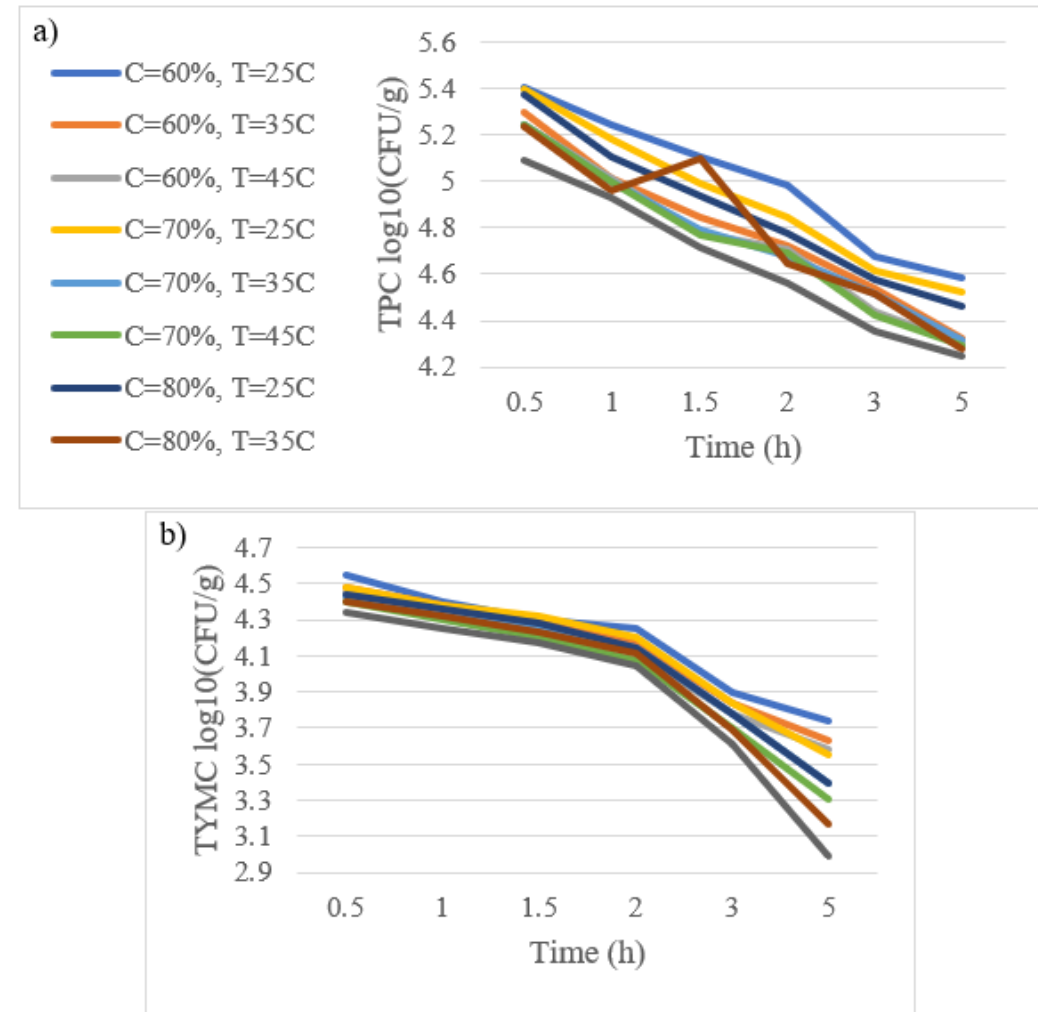

Figure 2. Changes in total plate counts (TPC) and total yeasts and moulds count (TYMC ) of mushrooms during osmotic dehydration in sugar beet molasses 
applied technological parameters. Values of Enterobacteriaceae were reduced to $<1.00$ $\log 10(\mathrm{CFU} / \mathrm{g})$ in all osmodehydrated samples, regardless of applied technological parameters. The effect of the process duration had statistically significant influence on the TPC and TYMC $\log 10$ (CFU/g) values, where prolonged duration of the osmotic dehydration process led to higher reduction of present microorganisms. An increase in process temperature significantly decreased TPC and TYMC. The effect of molasses concentration exerted also significant effect on both TPC and TYMC in such a way that an increase in the molasses concentration caused a significant decrease in TPC and TYMC. Prolonged duration of osmotic dehydration has led to the longer exposure of selected microorganisms to high osmotic pressure environment of osmotic solutions. Higher values of temperature and molasses concentration has led to the intensified mass transfer of the process, and reduced $\mathrm{a}_{\mathrm{w}}$ value. As a consequence, the treated samples provided unfavourable conditions for the growth and development of the tested microorganisms. Studies on the effect of osmotic dehydration parameters on pork and chicken meat microbiological profiles showed similar results (Filipović et al. 2019; Filipović et al., 2012).

Regarding microbiological safety, the osmodehydrated mushrooms are not ready-to-eat products so they are not covered by the ordinance of Comission Regulation (EC) 2073/2005. According to the other legal acts, such as the national regulation on sanitary requirements during food processing and trading (Pravilnik o opštim i posebnim uslovima higijene hrane u bilo kojoj fazi proizvodnje, prerade i prometa (2010)) it could be concluded that the detection of low number of Enterobacteriaceae in the mushrooms dehydrated in molasses indicates satisfactory hygiene of the production process.

\section{Effect on the chemical composition and mineral content in the treated mushrooms}

The fresh mushroom samples contained $3312.53 \pm 79.64 ; \quad 185.36 \pm 5.76 ; \quad 90.43 \pm 5.46$; $23.53 \pm 0.22$ and $\mathrm{mg} / \mathrm{kg}_{\text {d.m. }} \mathrm{K}, \mathrm{Ca}, \mathrm{Mg}$, and $\mathrm{Fe}$, respectively and $24.43 \pm 0.57 ; 26.22 \pm 0.35$ and $9.17 \pm 0.18 \%_{\text {d.m. }}$. proteins, sugars and ash, respectively (Supplementary material, Tables S3 and S4).
Osmotic dehydration process, through increasing solid matter of dehydrating samples (Rastogi \& Raghavarao, 2004; Chiralt \& Fito, 2003), statistically significantly affected the amounts of all tested minerals and chemical parameters. There was a statistically significant increase in $\mathrm{K}, \mathrm{Ca}, \mathrm{Mg}, \mathrm{Fe}$, sugars and ash contents as well as a significant decrease in protein content (comparing the significance level of run no. 0 with any other dehydrated sample, except the samples dehydrated during $0.5 \mathrm{~h}$, at $\mathrm{p}<0.05$, Suplementary material, Tables S3 and S4). Figures 3 and 4 depicts the changes in the content of minerals and proximal chemical composition of treated mushrooms during the osmotic dehydration in molasses. Increase in the content of minerals is a direct consequence of solid matter uptake from molasses which is abundant in these components. A decrease in the osmodehydrated mushrooms protein content is a result of nonprotein solid matter uptake (molasses is not a protein source), resulting in a relative decrease of dry matter protein content, although absolute quantities of mushrooms protein contents did not change during the osmotic dehydration process.

The concentrations of minerals and chemical parameters in the mushrooms treated at the applied highest levels of processing parameters (5-hour process duration, at $45{ }^{\circ} \mathrm{C}$, in $80 \%$ molasses) were the following: $8917.78 \pm 152.90, \quad 1241.23 \pm 4.06, \quad 1105.08 \pm$ 13.182 and $35.02 \pm 0.73 \mathrm{mg} / \mathrm{kg}$ for $\mathrm{K}, \mathrm{Mg}, \mathrm{Ca}$ and $\mathrm{Fe}$, respectively, and $16.35 \pm 0.19$, $38.49 \pm 0.34$ and $10.39 \pm 0.18 \%$ for protein, sugar and ash contents, respectively.

The effects of individual process parameters on mineral and chemical responses are the same as in the case of basic osmotic dehydration process parameters, since process mass transfer mechanisms are leading to compositional changes of the dehydrating samples. Individual increase of process time, temperature and molasses concentration has led to the statistically significant increase of minerals, sugars and ash, and a significant decrease of protein content. These results are in correlation with previously reported results on mineral and chemical composition of osmodehydrated fish (Lončar et al., 2015), pork meat (Nićetin et al., 2015b) and wild garlic (Šobot et al., 2019). 

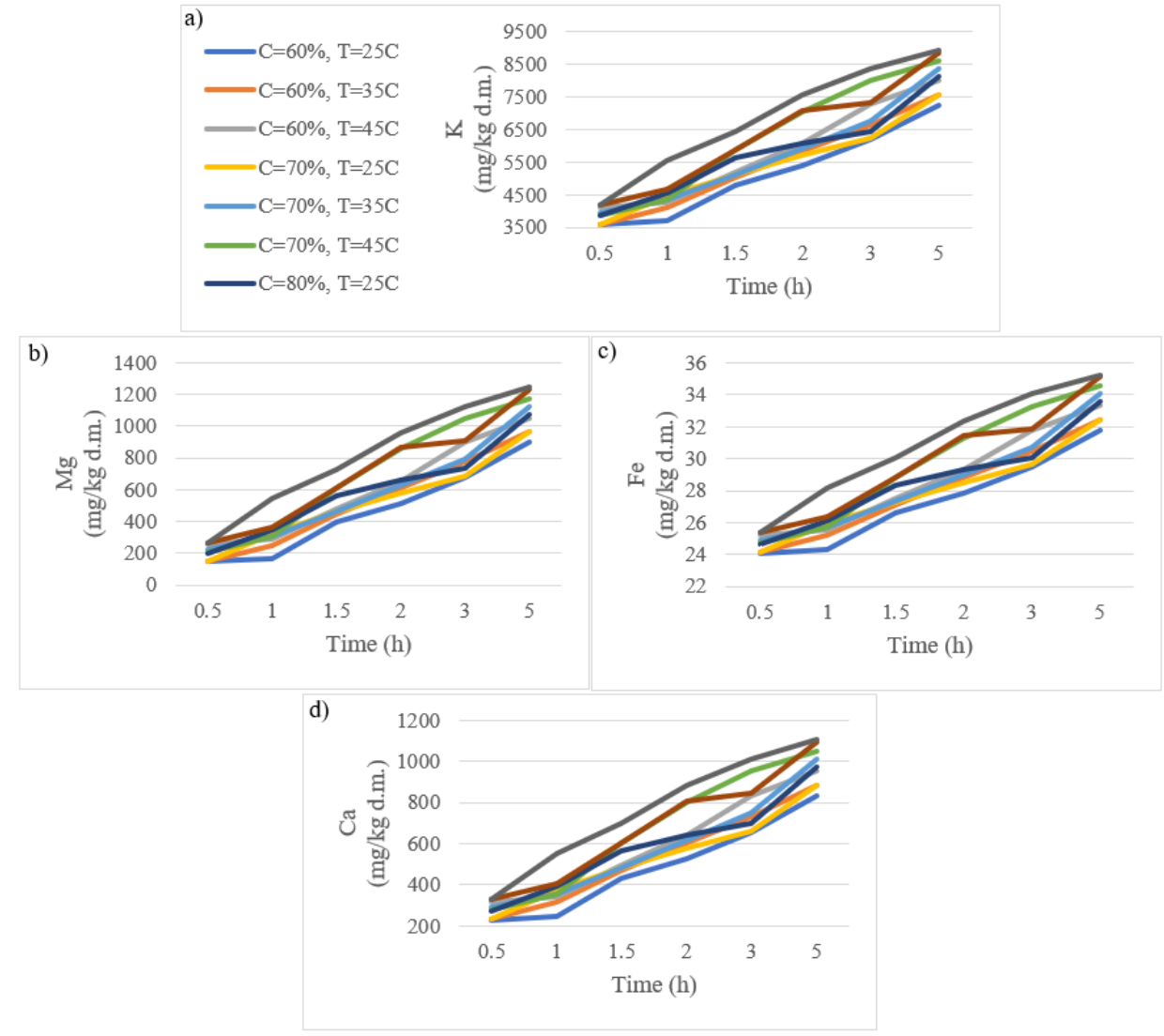

Figure 3. Uptake of minerals ( $\mathrm{K}, \mathrm{Ca}, \mathrm{Mg}$ and $\mathrm{Fe}$ ) in mushrooms during osmotic dehydration in sugar beet molasses

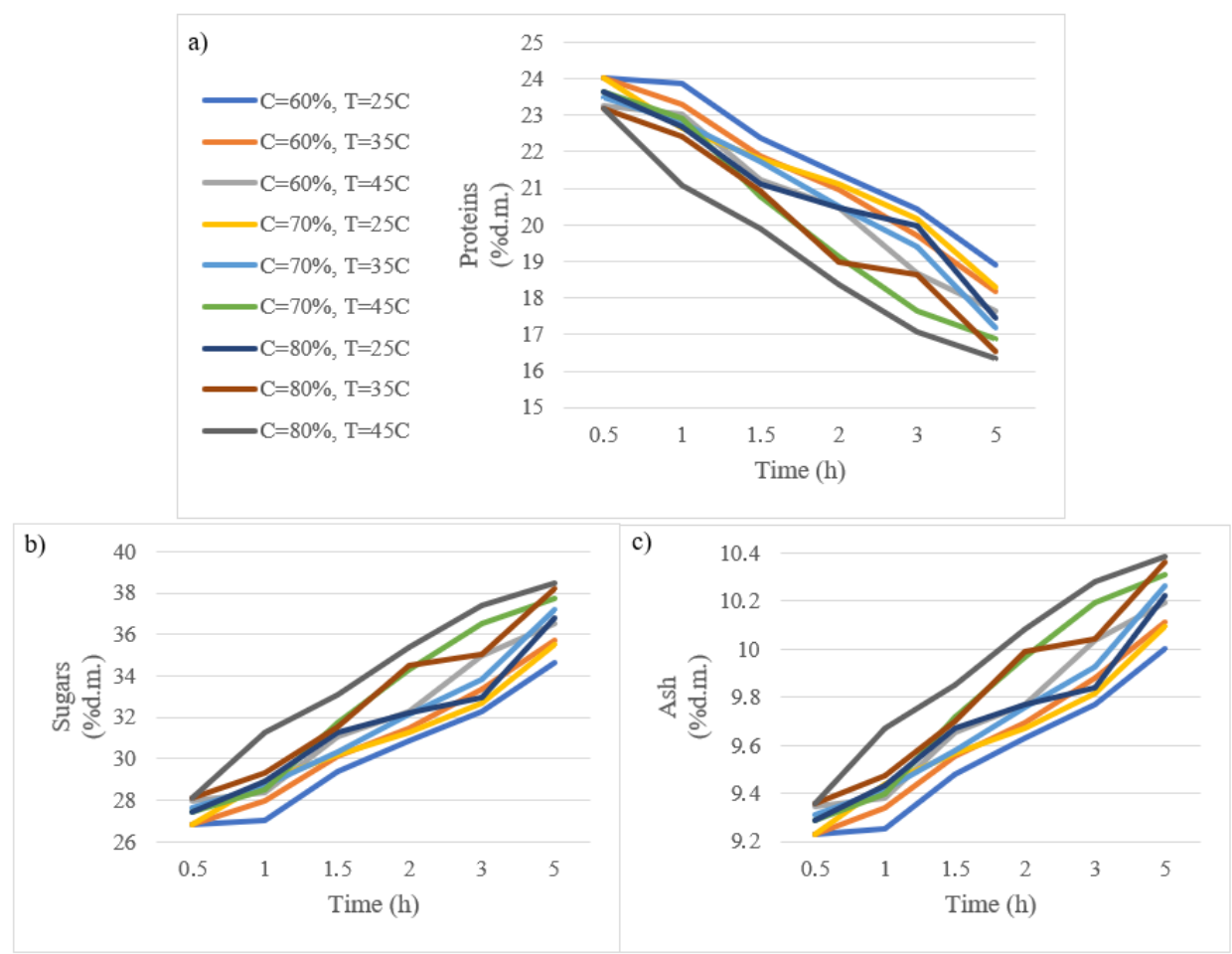

Figure 4. Changes in proximal chemical composition of mushrooms during osmotic dehydration in sugar beet molasses 
Table 2.

Variance analysis of the model for the osmotic dehydration process responses

\begin{tabular}{|c|c|c|c|c|c|c|}
\hline \multirow{2}{*}{$\begin{array}{l}\text { Technological } \\
\text { parameters }\end{array}$} & \multirow[t]{2}{*}{ Term } & \multirow{2}{*}{$\mathbf{d f}^{+}$} & \multicolumn{4}{|c|}{ Sum of squares } \\
\hline & & & DMC & WL & SG & $\mathbf{a}_{\mathbf{w}}$ \\
\hline \multirow[t]{2}{*}{ Time } & Linear & 1 & $4377.736^{*}$ & $0.900677^{*}$ & $0.031284 *$ & $0.031313 *$ \\
\hline & Quadratic & 1 & 9.752 & $0.052920 *$ & $0.000349 *$ & $0.000541 *$ \\
\hline \multirow[t]{2}{*}{ Temperature } & Linear & 1 & $1522.139 *$ & $0.310866^{*}$ & $0.003132 *$ & $0.007109 *$ \\
\hline & Quadratic & 1 & $133.521^{*}$ & $0.037826^{*}$ & 0.000000 & $0.000367 *$ \\
\hline \multirow[t]{2}{*}{ Concentration } & Linear & 1 & $182.165^{*}$ & $0.033919^{*}$ & $0.002897 *$ & $0.003183^{*}$ \\
\hline & Quadratic & 1 & 3.728 & 0.000155 & 0.000003 & 0.000038 \\
\hline \multirow[t]{3}{*}{ Cross product } & Time $\mathrm{x}$ Temperature & 1 & $141.004 *$ & 0.000372 & $0.000525^{*}$ & $0.001543 *$ \\
\hline & $\begin{array}{l}\text { Time } \mathrm{x} \\
\text { Concentration }\end{array}$ & 1 & $50.149 *$ & $0.011242 *$ & $0.000422 *$ & $0.000732 *$ \\
\hline & $\begin{array}{l}\text { Temperature } \mathrm{x} \\
\text { Concentration }\end{array}$ & 1 & 7.611 & 0.000003 & 0.000053 & 0.000001 \\
\hline \multirow[t]{2}{*}{ Linear } & Residual variance & 44 & 195.494 & 0.051955 & 0.001439 & 0.001378 \\
\hline & Total sum of squares & 53 & 6494.416 & 1.421158 & 0.038857 & 0.043641 \\
\hline $\mathrm{R}^{2}$ & & & 0.9699 & 0.9634 & 0.96296 & 0.96841 \\
\hline
\end{tabular}

Increasing the temperature, process duration and molasses concentration solid gain increases that affects the chemical and nutritional composition of the final product. The driving force for osmotic water removal is the concentration gradient established on opposite sides of the cell membrane. During dehydration, two counter current flows take place: water from the material passes into osmotic solution, while the dissolved substances of the osmotic solution diffuse into the material to be treated (Rodrigues and Mauro, 2004). Molasses concentration, regarding rich chemical and nutrient composition, contributes to substrate enrichment during osmotic dehydration.

\section{Analysis of the mathematical models for mass transfer during osmotic dehydration}

Table 2 shows ANOVA results of the response surface models which were calculated from the osmodehydration process responses $\left(\mathrm{DMC}, \mathrm{WL}, \mathrm{SG}, \mathrm{a}_{\mathrm{w}}\right.$ ) at different time, temperature and molasses concentration. ANOVA testing showed that all four responses were statistically significantly influenced by all three technological parameters, where the parameter with the highest influence was duration, followed by temperature and molasses concentration. In all four mathematical models of osmodehydration process responses, all three linear terms (for time, temperature and concentration) were statistically significant. Statistically significant model members are marked with * in Table 2. Quadratic term for time statistically significantly contributed to the model forming of WL, SG and $a_{w}$, in- dicating that exchange of masses occurred at a faster rate at the initial phase of the process followed by a reduction in drying rate during further processing time (Ramaswamy, 2005).

In the case of quadratic term for temperature, it was statistically significant for DMC, WL and $\mathrm{a}_{\mathrm{w}}$.

Interaction of time and concentration was significant in cases of all four responses, while the cross product Time $\mathrm{x}$ Temperature was significant in cases of: DMC, SG and $\mathrm{a}_{\mathrm{w}}$.

Residual variance was not statistically significant in any of four tested mathematical models, and together with high values od coefficient of correlation $\left(\mathrm{R}^{2}\right)$ pointed that the applied models adequately represented variation in osmotic process responses within the range of applied technological parameters.

\section{Analysis of the mathematical models for microbiological counts}

ANOVA results of the response surface models calculated from the recorded microbiological responses are shown in Table 3. Response for Enterobacteriacea were not modelled, since there was not enough variation between the experimental results. ANOVA testing showed that both modelled responses (TPC and TYMC) were statistically significantly influenced by all three technological parameters, where the most influential parameter was time, followed by temperature and the least influential molasses concentration. The increase in immersion time, pro- 
cess temperature and osmotic solution concentration lead to higher and accelerated moisture loss until equilibrium level is achieved (Mundada et al., 2011; Khan, 2012; Tortoe, 2010).

Table 3.

Variance analysis of the model for changes in the microbiological responses

\begin{tabular}{llccc} 
Technological & Term & \multirow{2}{*}{$\mathbf{d f}^{+}$} & \multicolumn{2}{c}{ Sum of squares } \\
parameters & & TPC & TYMC \\
\hline Time & Linear & 1 & $4.759147^{*}$ & $6.781457^{*}$ \\
& Quadratic & 1 & $0.584806^{*}$ & 0.008988 \\
Temperature & Linear & 1 & $0.401177^{*}$ & $0.193637^{*}$ \\
& Quadratic & 1 & $0.022711^{*}$ & 0.000083 \\
Concentration & Linear & 1 & $0.043333^{*}$ & $0.313438^{*}$ \\
& Quadratic & 1 & 0.000002 & 0.000052 \\
Cross product & Time x Temperature & 1 & 0.001275 & $0.033880^{*}$ \\
& Time x Concentration & 1 & 0.000005 & $0.154575^{*}$ \\
Linear & Temperature x Concentration & 1 & 0.001295 & 0.004181 \\
& Residual variance & 44 & 0.145756 & 0.162417 \\
& Total sum of squares & 53 & 5.800317 & 7.504803 \\
\hline $\mathrm{R}^{2}$ & & & 0.97487 & 0.97836 \\
\hline *Statistically significant at significance level of $p<0.05$ & & & \\
$d^{+}$- degrees of freedom & & &
\end{tabular}

Table 4.

Variance analysis of the model for mineral composition

\begin{tabular}{|c|c|c|c|c|c|c|}
\hline \multirow{2}{*}{$\begin{array}{l}\text { Technological } \\
\text { parameters }\end{array}$} & \multirow[t]{2}{*}{ Term } & \multirow{2}{*}{$\mathbf{d f}^{+}$} & \multicolumn{4}{|c|}{ Sum of squares } \\
\hline & & & $\mathbf{K}$ & Mg & $\mathbf{F e}$ & $\mathbf{C a}$ \\
\hline \multirow[t]{2}{*}{ Time } & Linear & 1 & 109780640* & $4632787 *$ & $484.3570 *$ & $2979382 *$ \\
\hline & Quadratic & 1 & $7593746 *$ & $321768 *$ & $34.2301 *$ & $206338^{*}$ \\
\hline \multirow[t]{2}{*}{ Temperature } & Linear & 1 & $6848700 *$ & $286218^{*}$ & $32,9853^{*}$ & $185128 *$ \\
\hline & Quadratic & 1 & 17144 & 721 & 0.0204 & 560 \\
\hline \multirow{2}{*}{ Concentration } & Linear & 1 & 6039284* & $253727 *$ & $32.4158^{*}$ & $162932 *$ \\
\hline & Quadratic & 1 & 59476 & 2821 & 0.1135 & 1666 \\
\hline \multirow[t]{3}{*}{ Cross product } & Time $\cdot$ Temperature & 1 & $412475^{*}$ & $17289^{*}$ & $2.1359^{*}$ & $11239 *$ \\
\hline & $\begin{array}{l}\text { Time } \\
\text { Concentration }\end{array}$ & 1 & 127673 & 5334 & 0.6506 & 3329 \\
\hline & $\begin{array}{l}\text { Temperature - } \\
\text { Concentration }\end{array}$ & 1 & 218477 & 9267 & 0.4653 & 5733 \\
\hline \multirow[t]{2}{*}{ Linear } & Residual variance & 44 & 3998398 & 166226 & 19.6996 & 109882 \\
\hline & Total sum of squares & 53 & 131522730 & 5545108 & 591.0625 & 3569327 \\
\hline $\mathrm{R}^{2}$ & & & 0.9696 & 0.97002 & 0.9666 & 0.96221 \\
\hline
\end{tabular}

Table 5.

Variance analysis of the model for chemical composition responses

\begin{tabular}{|c|c|c|c|c|c|}
\hline \multirow{2}{*}{$\begin{array}{l}\text { Technological } \\
\text { parameters }\end{array}$} & \multirow[t]{2}{*}{ Term } & \multirow{2}{*}{$\mathbf{d f}^{+}$} & \multicolumn{3}{|c|}{ Sum of squares } \\
\hline & & & Proteins & Sugars & Ash \\
\hline \multirow{2}{*}{ Time } & Linear & 1 & $225.6559 *$ & $520.8845^{*}$ & $5.133447 *$ \\
\hline & Quadratic & 1 & $15.8561 *$ & $36.6009^{*}$ & $0.360711^{*}$ \\
\hline \multirow[t]{2}{*}{ Temperature } & Linear & 1 & $15.4544 *$ & $35.736^{*}$ & 0.351572 \\
\hline & Quadratic & 1 & 0.0351 & 0.0810 & 0.000798 \\
\hline \multirow[t]{2}{*}{ Concentration } & Linear & 1 & $12.3922 *$ & $28.6051^{*}$ & $0.281910^{*}$ \\
\hline & Quadratic & 1 & 0.0823 & 0.1899 & 0.001872 \\
\hline \multirow[t]{3}{*}{ Cross product } & Time $\mathrm{x}$ Temperature & 1 & $0.8952 *$ & $2.0664 *$ & $0.020364^{*}$ \\
\hline & Time $\mathrm{x}$ Concentration & 1 & 0.3051 & 0.7043 & 0.006941 \\
\hline & Temperature $\mathrm{x}$ Concentration & 1 & 0.2938 & 0.6782 & 0.006684 \\
\hline \multirow[t]{2}{*}{ Linear } & Residual variance & 44 & 8.0342 & 18.5454 & 0.182770 \\
\hline & Total sum of squares & 53 & 271.4764 & 626.6526 & 6.175817 \\
\hline $\mathrm{R}^{2}$ & & & 0.97041 & 0.9643 & 0.9743 \\
\hline
\end{tabular}

*Statistically significant at significance level of $p<0.05$

$d f^{+}$- degrees of freedom 
All three linear terms (for time, temperature and concentration) were statistically significant in cases of both microbiological responses. Quadratic terms of time and temperature statistically significantly contributed to the TPC model forming. Cross products Time $\mathrm{x}$ Temperature and Time $\mathrm{x}$ Concentration were significant in the case of TYMC.

Residual variance was not statistically significant in both tested mathematical models, and together with high $\mathrm{R}^{2}$ values showed that applied models adequately represented variations of microbiological profile responses.

\section{Analysis of the mathematical models for responses related to mineral and chemical composition}

Significant mineral enrichment and chemical composition change in the treated mushrooms is a consequence of previously explained mechanisms of solid gain upgrowth, owing to molasses favourable nutritional composition. Tables 4 and 5 shows the ANOVA results of the response surface models calculated for mineral and chemical composition, respecttively.

The presented results show that all seven responses were influenced by all three technological parameters, in the following order of significance: time, temperature, concentration. In cases of all responses, linear terms of all three dehydration parameters were statistically significant. Quadratic term for time, together with cross product of Time $\mathrm{x}$ Temperature were also statistically significant in all cases. Residual variance was not statistically significant in any of the tested mathematical models. High $\mathrm{R}^{2}$ values again indicated on good fit of proposed models to the minerals and chemical responses experimental data.

\section{Mathematical models regression coefficients}

Individual coefficients, which can be used for forming thirteen quadratic equations of models for selected responses (mass transfer parameters, microbiological counts, mineral and chemical composition), are shown in Supplemetary material, Tables S5 and 6, along with their statistical significance. Using presented equations and knowing technological parameters of the process (time, temperature and molasses concentration), values of all selected responses at the determined process conditions can be calculated. Data obtained from these models can be used for process and quality control and management of the osmotic dehydration of mushrooms in molasses.

\section{CONCLUSIONS}

From the presented results it can be concluded that osmotic dehydration of mushrooms in beet molasses and an increase in its intensity led to the significant increase in mass transfer kinetics, mineral uptake (for example, an increase in $\mathrm{K}$ content by $269.42 \%$; and $\mathrm{Ca}$ content increase by $939.03 \%$ ), changes in proximate chemical composition and a decrease in $\mathrm{a}_{\mathrm{w}}$ values (from 0.941 to 0.811 ), microbiological load and relative protein content $(33.07 \%$ decrease). The obtained osmodehydrated mushroom samples were characterized by high levels of DMC, low $\mathrm{a}_{\mathrm{w}}$ values and favourable microbiological profile, indicating a good base for prolonged shelf life and further processing. Improved nutritive profile of osmodehydrated mushrooms owing mostly to prominent mineral enrichment due to transfer of minerals from molasses, suggest a possibility for production of new and functional products. The proposed mathematical models of changes in selected responses (mass transfer parameters, microbiological counts, mineral and chemical composition) were statistically significant, calculated and observed responses corresponded very well, indicating a satisfactory approximation of responses values within the applied technological parameters.

\section{ACKNOWLEDGEMENTS}

This paper is a result of the research within the project TR 31055 (451-03-68/2020-14/ 200134), supported by the Ministry of Education, Science and Technology, Republic of Serbia.

\section{REFERENCES}

Ahmed, I., Qazi, I.M., \& Jamal, S. (2016). Developments in osmotic dehydration technique for the preservation of fruits and vegetables. Innovative Food Science and Emerging Technologies, 34, 29-43. https://doi.org/10.1016/j.ifset.2016.01.003

Amami, E., Fersi, A., Khezami, L., Vorobiev, E., \& Kechaou, N. (2007). Centrifugal osmotic dehydration and rehydration of carrot tissue pre-treated by pulsed electric field. LWT - Food Science and Technology, 40 (7), 1156-1166. https://doi.org/10.1016/j.lwt.2006.08.018

AOAC. (2000). Official methods of analysis. Washington D.C., USA: Association of Official Analytical Chemists. 
Chiralt, A., \& Fito, P. (2003). Transport mechanisms in osmotic dehydration: The role of the structure. Food Science and Technology International, 9(3), 179-186. https://doi.org/10.1177/1082013203034757

Ciurzyńska, A., Kowalska, H., Czajkowska, K., \& Lenart, A. (2016). Osmotic dehydration in production of sustainable and healthy food. Trends in Food Science and Technology, 50, 186-192. https://doi.org/10.1016/j.tifs.2016.01.017

Commission Regulation (EC) 2073/2005. (2005). Commission Regulation (EC) No 2073/2005 of 15 November 2005 on microbiological criteria for foodstuffs. Official Journal of the EU, 338, 1-26.

Ćurčić B., Pezo L., Filipović V., Nićetin M., \& Knežević V. (2015). Osmotic treatment of fish in two different solutions-artificial neural network model. Journal of Food Processing and Preservation, 39(6), 671-680. https://doi.org/10.1111/jfpp.12275.

Cvetković, B., Pezo, L., Mišan, A., Mastilović, J., Kevrešan, Ž., Ilić, N., \& Filipčev, B. (2019). The effects of osmotic dehydration of white cabbage on polyphenols and mineral content. LWT - Food Science and Technology, 110, 332-337. https://doi.org/10.1016/j.lwt.2019.05.001.

Darvishi, H., Azadbakht, M., \& Noralahi, B. (2018). Experimental performance of mushroom fluidizedbed drying: Effect of osmotic pretreatment and air recirculation. Renewable Energy, 120, 201-208. https://doi.org/10.1016/j.renene.2017.12.068.

Doymaz, I. (2014). Drying kinetics and rehydration characteristics of convective hot-air dried white button mushroom slices. Journal of Chemistry, 2014, Article ID 453175. https://doi.org/10.1155/2014/453175

Erle, U., \& Schubert, H. (2001). Combined osmotic and microwave-vacuum dehydration of apples and strawberries. Journal of Food Engineering, 49(23), 193-199. https://doi.org/:10.1016/S0260-8774(00)00207-7.

Falade, K.O., Igbeka, J.C., \& Ayanwuyi, F.A. (2007). Kinetics of mass transfer and colour changes during osmotic dehydration of watermelon. Journal of Food Engineering, 80(3), 979-985. https://doi:10.1016/j.jfoodeng.2006.06.033.

Fernandes, F.A.N., Gallão, M.I., \& Rodrigues, S. (2009). Effect of osmosis and ultrasound on pineapple cell tissue structure during dehydration. Journal of Food Engineering, 90(2), 186-190. https://doi.org/10.1016/j.jfoodeng.2008.06.021.

Filipović, I., Markov, S., Filipović, V., Filipović, J., Vujačić, V., \& Pezo, L. (2019). The effects of the osmotic dehydration parameters on reduction of selected microorganisms on chicken meat. Journal of Food Processing and Preservation, 43(10), 141144. https://doi.org/10.1111/jfpp.14144.

Filipović, V., Ćurčić, B., Nićetin, M., Plavšić, D., Koprivica G. \& Mišljenović, N. (2012). Mass transfer and microbiological profile of pork meat dehydrated in two different osmotic solutions. Hemijska Industrija, 66(5), 743-748. https://doi.org/10.2298/HEMIND120130033F.

Filipović, V., Lončar, B., Nićetin, M., Knežević, V., Filipović, I. \& Pezo, L. (2014). Modeling countercurrent osmotic dehydration process of pork meat in molasses. Journal of Food Process Engineering, 37(5), 533-542.

https://doi.org/10.1111/jfpe.12114.

González-Pérez, J.E., López-Méndez, E.M., Luna-Guevara, J.J., Ruiz-Espinosa, H., Ochoa-Velasco, C.E., \& Ruiz-Lópeza, I.I. (2019). Analysis of mass transfer and morphometric characteristics of white mushroom (Agaricus bisporus) pilei during osmotic dehydration. Journal of Food Engineering, 240, 120-132. https://doi.org/10.1016/j.jfoodeng.2018.07.026

Gupta, P., Bhat, A., Chauhan, H., Ahmed N., \& Malik, A. (2015). Osmotic dehydration of button mushroom. International Journal of Food and Fermentation Technology, 5(2), 177-182. https://doi.org/10.5958/2277-9396.2016.00003.9

ISO 21527-2:2008. (2008). Microbiology of food and animal feeding stuffs - Horizontal method for the enumeration of yeasts and moulds - Part 2: Colony count technique in products with water activity less than or equal to 0.95 .

ISO 21528-2:2017. (2017). Microbiology of the food chain - Horizontal method for the detection and enumeration of Enterobacteriaceae - Part 2: Colony-count technique.

ISO 4833-1:2013. (2013). Microbiology of the food chain - Horizontal method for the enumeration of microorganisms. Colony count at $30^{\circ} \mathrm{C}$ by the pour plate technique.

ISO 6869:2000. (2000). Animal feeding stuffs - Determination of the contents of calcium, copper, iron, magnesium, manganese, potassium, sodium and zinc - Method using atomic absorption spectrometry.

Ispir, A., \& Toğrul, Đ.T. (2009). Osmotic dehydration of apricot: Kinetics and the effect of process parameters. Chemical Engineering Research and Design, 87(2), 166-180. https://doi.org/10.1016/j.cherd.2008.07.011

Khan, M. R. (2012). Osmotic dehydration technique for fruits preservation - A review. Pakistan Journal of Food Sciences, 22(2), 71-85.

Knežević, V., Pezo, L., Lončar, B., Filipović, V., Nićetin, M., Gorjanović, S., \& Šuput D. (2019). Antioxidant capacity of nettle leaves during osmotic treatment. Periodica Polytechnica-Chemical Engineering, 63(3), 491-498. https://doi.org/10.3311/PPch.12688.

Koprivica, G., Pezo, L., Ćurčić, B., Lević, Lj., \& Šuput, D. (2014). Optimization of osmotic dehydration of apples in sugar beet molasses. Journal of Food Processing and Preservation, 38(4), 1705-1715. https://doi.org/10.1111/jfpp.12133.

Lončar, B., Filipović,V., Nićetin, M., Knežević, V., Gubić, J., Plavšić, D., \& Pezo L. (2015). Characterisation of chicken breast cubes osmotically treated in sugar beet molasses. Journal on Processing Energy in Agriculture, 19(4), 186-188.

Mišljenović, N., Koprivica, G., Jevrić, L., \& Lević, Lj. (2011). Mass transfer kinetics during osmotic dehydration of carrot cubes in sugar beet molasses. Romanian Biotechnological Letters, 16(6), 67906799. https://doi.org/10.2298/APT1041047K.

Mújica-Paz, H., Valdez-Fragoso, A., Lopez-Malo, A., Palou, E., \& Welti-Chanes, J. (2003). Impregnation and osmotic dehydration of some fruits: effect of the vacuum pressure and syrup concentration. 
Journal of Food Engineering, 57(4), 305-314. https://doi.org/10.1016/S0260-8774(02)00344-8.

Mundada, M., Hathan, B.S., \& Maske, S. (2011). Mass transfer kinetics during osmotic dehydration of pomegranate arils. Journal of Food Science, 75(1), 31-39. https://doi.org/10.1111/j.1750-3841.2010.01921.x

Nićetin, M., Pezo, L., Lončar, B., Filipović, V., Šuput, D., Knežević, V., \& Filipović, J. (2017). The possibility of increasing the antioxidant activity of celery root during osmotic treatment. Journal of the Serbian Chemical Society, 82(3), 253-265. https://doi.org/10.2298/JSC161020015N.

Nićetin, M., Lončar, B., Filipović, V., Knežević, V., Kuljanin, T., Pezo, L., \& Plavšić, D. (2015a). The change in microbiological profile and water activity due to the osmotic treatment of celery leaves and root. Journal on Processing Energy in Agriculture, 19(4), 193-196.

Nićetin, M., Pezo L., Lončar, B., Filipović, V., Šuput, D., Zlatanović, S., \& Dojčinović, B. (2015b). Evaluation of water, sucrose and minerals effective diffusivities during osmotic treatment of pork in sugar beet molasses. Hemijska Industrija, 69(3), 241-251. https://doi.org/10.2298/HEMIND131003037N.

Phisut, N. (2012). Factors affecting mass transfer during osmotic dehydration of fruits. International Food Research Journal, 19(1), 7-18.

Pravilnik o opštim i posebnim uslovima higijene hrane u bilo kojoj fazi proizvodnje, prerade i prometa. (2010). Sl. glasnik RS, 72/2010; 62/2018.

Qiu, L., Zhang, M., Tang, J., Adhikari, B., \& Cao, P. (2019). Innovative technologies for producing and preserving intermediate moisture foods: A review. Food Research International, 116, 90-102. https://doi.org/10.1016/j.foodres.2018.12.055.

Rahman, M.S., \& Perera, C. (2007). Drying and food preservation. In M. Shafiur Rahman (Ed.), Handbook of food preservation ( $2^{\text {nd }}$ ed.). Boca Raton, FL: CRC Press.

Ramaswamy, H. S. (2005). Osmotic drying. In The Workshop on Drying of Food and Pharmaceuticals at the Fourth Asia Pacific Drying Conference. Kolkata, India.

Rastogi, N.K., \& Raghavarao, K.S.M.S. (2004). Mass transfer during osmotic dehydration of pineapple: considering Fickian diffusion in cubical configuration. LWT - Food Science and Technology, 37(1), 43-47. https://doi.org/10.1016/S0023-6438(03)00131-2.

Rodrigues, A.E., \& Mauro, M.A. (2004). Water and sucrose diffusion coefficients in apple during osmotic dehydration. In Proceedings of the $14^{\text {th }}$ International Drying Symposium. São Paulo, Brazil.

Sauvant, D., Perez, J.M., \& Tran, G. (2004). Tables de composition et de valeur nutritive des matières premières destinées aux animaux d'élevage: Porcs, volailles, bovins, ovins, caprins, lapins, chevaux, poisons (2ème édition revue et corrigée). Versailles, France: INRA Editions.

Shi, J., \& Xue, J.S. (2009). Application and development of osmotic dehydration technology in food processing. In C. Ratti (Ed.), Advances in food dehydration. USA: CRC Press.
Silva, K.S., Fernandes, M.A., \& Mauro, M.A. (2014). Effect of calcium on the osmotic dehydration kinetics and quality of pineapple. Journal of Food Engineering, 134, 37-44. https://doi.org/10.1016/j.jfoodeng.2014.02.020.

Šarić, Lj., Filipčev, B., Šimurina, O., Plavšić, D., \& Šarić, B. (2016). Sugar beet molasses: properties and applications in osmotic dehydration of fruits and vegetables. Food and Feed Research, 43(2), 135144. https://doi.org/10.5937/FFR1602135Š.

Šobot, K., Laličić-Petronijević, J., Filipović, V., Nićetin, M., Filipović, J. \& Popović, Lj. (2019). Contribution of osmotically dehydrated wild garlic on biscuits' quality parameters. Periodica Polytechnica Chemical Engineering, 63(3), 499-507. https://doi.org/10.3311/PPch.13268.

Šuput, D., Lazić, V., Pezo, L., Gubić, J., Šojić, B., Plavšić, D., Lončar, B., Nićetin, M., Filipović, V. \& Knežević, V. (2019). Shelf life and quality of dehydrated meat packed in edible coating under modified atmosphere. Romanian Biotechnological Letters, 24(3), 545-553. https://doi.org/10.25083/rbl/24.3/545.553.

Tortoe, C. (2010). A review of osmodehydration for food industry. African Journal of Food Science, 4(6), 303-324.

Waliszewski, K.N., Delgado, J.L., \& Garcia M.A. (2002). Equilibrium concentration and water and sucrose diffusivity in osmotic dehydration of pineapple slabs. Drying Technology, 20, 527-538. https://doi.org/10.1081/DRT-120002555.

\section{SUPPORTING INFORMATION}

Additional Supplementary material may be found in the online version of this article.

Table S1. Experimental data for osmotic dehydration mass transfer responses

DMC (\%) - Dry matter content; WL (g/gis. $)$-Water loss; SG (g/gi.s.) - Solid gain; $\mathrm{a}_{\mathrm{w}}$ - Water activity

Table S2. Experimental data for microbiological responses

TPC $(\log 10(\mathrm{CFU} / \mathrm{g}))$ - Total plate count; Enterobactericeae $(\log 10(\mathrm{CFU} / \mathrm{g}))$; TYMC $(\log 10(\mathrm{CFU} / \mathrm{g}))$ - Total yeasts and moulds count

Table S3. Experimental data for responses related to mineral composition

$\mathrm{K}, \mathrm{Mg}, \mathrm{Ca}$ and $\mathrm{Fe}$ content in $\mathrm{mg} / \mathrm{kg}_{\mathrm{d} . \mathrm{m}}$.

Table S4. Experimental data of chemical composition responses

Content of ash, sugars and proteins in $\%_{\text {d.m. }}$.

Table S5. Regression coefficients of SOP models for osmotic dehydration process and microbiological responses

Table S6. Regression coefficients of SOP models for minerals and chemical responses 


\section{МОДЕЛОВАЊЕ ПРОЦЕСА ОСМОТСКЕ ДЕХИДРАТАЦИЈЕ ПЕЧУРАКА (AGARICUS BISPHORUS) У МЕЛАСИ ШЕЋЕРHE РEПE}

Данијела 3. Шупут*¹, Владимир С. Филиповић ${ }^{1}$, Биљана Љ. Лончар ${ }^{1}$, Милица Р. Нићетин ${ }^{1}$, Виолета М. Кнежевић ${ }^{1}$, Јасмина М. Лазаревић ${ }^{2}$, Драгана В. Плавшић ${ }^{2}$

${ }^{1}$ Универзитет у Новом Саду, Технолошки факултет Нови Сад, 21000 Нови Сад, Булевар цара Лазара бр. 1, Србија

${ }^{2}$ Универзитет у Новом Саду, Научни институт за прехрамбене технологије у Новом Саду, 21000 Нови Сад, Булевар цара Лазара бр. 1, Србија

Сажетак: Печурке (Agaricus bisphorus) су осмотски дехидриране у растворима меласе шећерне репе различитих концентрација $(60 \%, 70 \%$ и $80 \%)$, на радним температурама од 25,35 и $45{ }^{\circ} \mathrm{C}$ током $0,5,1,1,5,2,3$ и $5 \mathrm{~h}$. Садржај влаге, активност воде $\left(\mathrm{a}_{\mathrm{w}}\right)$, микробиолошки квалитет (укупан број бактерија, ентеробактерије, укупан број квасца и плесни) и садржај минералних материја (садржај калијума, калцијума, магнезијума и гвожђа) одређени су на добијеним узорцима осмотски дехидрираних печурака. Методи одзивних површина и анализе варијансе одабрани су да би се проценили главни ефекти процесних варијабли на микробиолошки квалитет, садржај минералних материја и хемијски састав осмотски дехидрираних печурака. Повећање вредности процесних параметара осмотске дехидратације довело је до значајног повећања садржаја минералних материја (на пример, пораст садржаја K за 269,42\% и садржаја Са за 939.03\%), а смањења вредности активности воде (са 0,941 на 0,811 ), микробиолошког оптерећења и релативног садржаја протеина (пад од $33,07 \%$ ) у дехидрираним узорцима печурака, што указује на могућност продуженог рока трајања и погодности овако обрађених печурака за даљу обраду. Осмотски дехидриране печурке могу се сматрати новим функционалним (полу)производима, узимајући у обзир њихов побољшан нутритивни профил.

Кључне речи: минерални састав, губитак влаге, прираст суве материје, тікробиолошки квалитет, хемијски састав

Received: 16 September 2020/Received in revised form: 08 December 2020/Accepted: 10 December 2020

Available online: December 2020

This is an open-access article under the CC BY license (http://creativecommons.org/licenses/by/3.0). 